\title{
Multi-Year and Seasonal Variations of the Constant Halocline Characteristics in the Eastern Part of the Black Sea
}

\author{
B.N. Panov, E.O. Spiridonova \\ Kerch State Maritime Technological University, Kerch, Russian Federation \\ e-mail:panov_bn@mail.ru
}

\begin{abstract}
The existing notions of divergent processes and multi-year trends in the variability of hydrophysical fields of the upper water layer and the Black Sea main pycnocline layer, as well as the contradictions noted in the discussion of the causes of vertical movements of the Black pycnocline and seasonal variation of the water circulation intensity determine the relevance of the pycnocline structure research.

The present paper is aimed at studying the features of spatial and temporal variations of the Black Sea main halocline characteristics used as indicators of water circulation.

Features of multi-year and seasonal changes in the characteristics of three types of constant halocline state corresponding to the water upwelling and downwelling zones in the eastern Black Sea in 1955 1994 are considered. Application of the proposed indices permits to reveal that in multi-year changes of the halocline depth and intensity, the most important ones are the processes taking place in deep anticyclonic eddies, and as for inter-year and seasonal variability - the processes in small anticyclonic eddies. The main feature of the processes under examination consists in predominance of synchronism in gradient changes of the halocline salinity and depth in various dynamic formations. Compensating asynchronism of the halocline vertical movements in the water upwelling and downwelling zones is manifested only at decrease of time and space scales of data averaging up to the seasonal values and the dimension $2^{\circ}$ lat. $\times 4^{\circ}$ long., respectively.

In the north-eastern sea area the vorticity intensification of currents was observed in October December and was due in equal measure to the strengthening of cyclonic and anticyclonic vorticity of currents. In the south-eastern sea area the vorticity intensification occurred either in January - March or in July - September mainly due to the intensification of anticyclonic vorticity.
\end{abstract}

Keywords: the Black Sea, constant halocline, synoptic eddies, seasonal and interannual variability

DOI: 10.22449/1573-160X-2015-2-51-58

(c) 2015, B.N. Panov, E.O. Spiridonova

(C) 2015, Physical Oceanography

Introduction. Activation of the field hydrophysical research in the Black Sea in 80-s of the previous century permitted the significant widening of our conception of water circulation spatio-temporal variability peculiarities. The research resulted in the conclusion that the medium-scaled synoptic nonstationarity mode, also manifested in the long-term variability, prevailed in the Black Sea water circulation $[1,2]$.

The principal cause of the synoptic variability is eddy formations and the Main Black Sea Current (MBSC) meanders, having the maximum of the available potential energy density in the layer of the constant halocline [3]. So, it's evident that halocline characteristics can be applied as the water circulation spatio-temporal variability indices.

In the last years, due to the improving of the oceanographic monitoring distance and drift methods, the knowledge on the Black Sea upper layer water circulation significantly improved. The contemporary circulation models with the high spatial resolution permit to research the eddy structure variability of the currents on the various depths.

However, the existing conceptions of the multidirectional processes and longterm trends in variability of the hydrophysical fields of the upper layer waters and main halocline layer [4 - 8] and also the contradictions marked during the discussion of the causes of the Black Sea pycnocline vertical movements [9] and 
seasonal course of water circulation intensity [10] still permit to consider the pycnocline structure research actual.

The aim of the present article is to study spatio-temporal variability peculiarities of the halocline characteristics applied as the water circulation indices.

Research materials and methods. In the work [11] it was demonstrated that identification the dynamic formations in the Black Sea water geostrophic circulation is possible by simultaneous application of the constant halocline position depth $(H)$ and maximum salinity gradient value in it $(I)$, combining high $\left(H_{\mathrm{h}}, I_{\mathrm{h}}\right)$ and low $\left(H_{\mathrm{l}}, I_{\mathrm{l}}\right)$ values of this indices, as follows:

- $H_{\mathrm{h}} I_{\mathrm{h}}$ is deep position of the peaked halocline (HH-type halocline), corresponds to the areas of small anticyclonic eddies (further SAE) and weak coastal downwelling of waters;

- $H_{\mathrm{l}} I_{\mathrm{h}}$ is high position of the peaked halocline (LH-type halocline), corresponds to the areas of cyclonic eddies (CE) and coastal upwellings;

- $H_{\mathrm{h}} I_{\mathrm{l}}$ is deep position of the diffused halocline (HL-type halocline), corresponds to the areas of deep anticyclonic eddies (further DAE) and coastal downwelling of waters at the MBSC periphery.

High and low indices were determined under the oceanographic survey data according to the following formula:

$$
\begin{array}{cc}
H_{\mathrm{h}}>H_{\text {med }}+\sigma H, & I_{\mathrm{h}}>I_{\text {med }}+\sigma I ; \\
H_{\mathrm{l}}<H_{\text {med }}-\sigma H, & I_{\mathrm{l}}<I_{\text {med }}-\sigma,
\end{array}
$$

where $\sigma H$ and $\sigma$ are medium quadratic deviations of the values $H$ and $I$.

Halocline characteristics were calculated according the materials of the 416 expeditions to the oceanographic stations (total 24479), carried out by South Scientific Research Institute of Marine Fisheries and Oceanography (YUGNIRO), Marine Hydrophysical Institute (MHI) and Ukrainian Scientific Center of Ecology of Sea (UkrSCES) from 1954 to 1996 in the eastern Black Sea (35 E).

As a result of the sampling performed, an array of three stations (total 7273) was formed, which data cover the period from 1955 to 1994 and characterize three types of halocline in areas of SAE, CE and DAE in the eastern part of the sea, as well as corresponding arrays for the north-eastern and south-eastern subareas (Fig. 1), different by the peculiarities of water circulation.

Methods of determining the characteristics of the selected types of the constant Black Sea halocline and forming rows of their average annual values set out in the work [12].

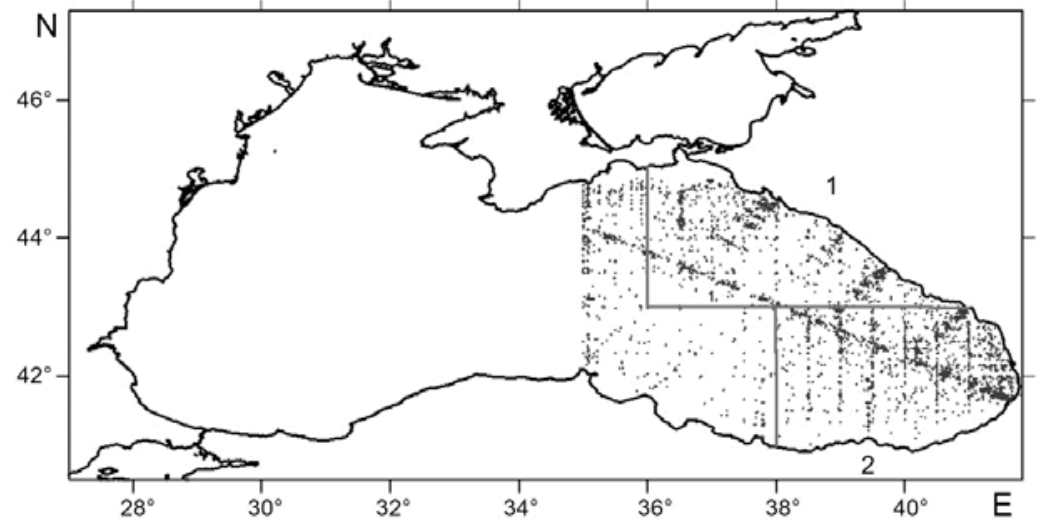

Fig. 1. Position of the oceanographic stations (total 7273), carried out in 1955 - 1994, with their data characterizing three considered types of halocline in the eastern part of the Black Sea (1 and $2-$ the north-eastern and south-eastern subareas correspondingly) 
The used database also permitted to research the peculiarities of the seasonal changes of the characteristics of the considered halocline types in the whole eastern part of the sea within 20 year period at the interval from 1959 to 1992 г., in the north-eastern subarea - for the following years: 1969, 1971, 1981, 1982 and 1988, in the south-eastern one - for the period of $1983-1989$.

Seasonal data were used in the analysis, provided each type of halocline in the season was characterized by materials of three or more deep-sea stations.

Relationship of the changes in the characteristics of the considered halocline types was determined by the correlation coefficient. The relations with the level of significance $\geq 0.95$ were accepted statistically significant.

The results of research. The information about interannual changes and longterm trends in the variability of average annual values of salinity gradient and depth of the halocline position can be obtained from the graphs shown in Fig. 2.

For SAE areas the growth of halocline depth position (in the range of $100-$ $130 \mathrm{~m}$ ) to the mid 70s (more intense in the south-east subarea), then its decrease (more intense in the north-east subarea) can be noted. The maximum salinity gradient in these areas from the mid 70s to mid 80s increases (more intense in the north-east subarea) in the range of $0.035-0.055 \% / \mathrm{m}$, then (in the mid 90s) decreases.

As per DAE areas for their both subareas there is a steady trend of reducing the depth of the halocline in the range of $100-140 \mathrm{~m}$ from the beginning of the 70s until the end of the research period. A distinctive feature of the change of maximum salinity gradient in this type of a halocline is a threshold character. Prior to the 80 s the relative stability of the values was remained within the $0.023-$ $0.027 \% / \mathrm{m}$, in the early 80 s there was a sharp (for $3-4$ years) growth of the gradient, and then its stabilization was observed at the level of $0.032-0.034 \% / \mathrm{m}$.
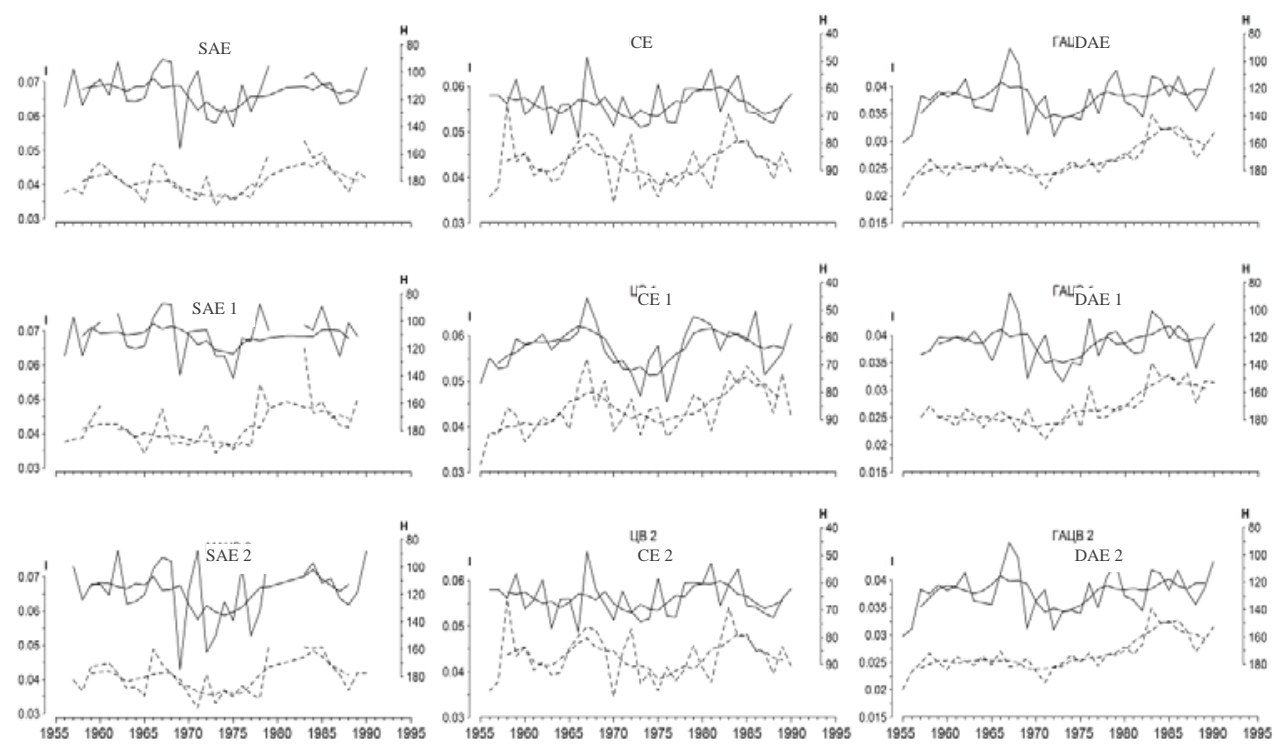

Fig. 2. Long-term changes of the average annual values (smoothed by the 5 -year moving averaging) of the maximum salinity gradient $I(\% \mathrm{o} / \mathrm{m})$ and its position depth $H(\mathrm{~m})$ in he constant halocline in the eastern Black Sea for SAE, CE and DAE areas (1 and 2 - north-eastern and south-eastern areas correspondingly; $H$ - continuous curves, $I$ - dashed curves) 
The clearer expressed oscillation processes of the average annual values (2 - 3 cycles during the research period), which don't match under the phase, should be noted for halocline characteristics in CE areas. Changes of the depth of halocline position mainly occur in the range of 45 to $75 \mathrm{~m}$, of the salinity gradient - of 0.035 to $0.050 \% / \mathrm{m}$. Growth of the gradient and decrease of the depth of halocline position in the water upwelling areas of the both subareas from the mid 70s to mid 80s were particularly intense. These peculiarities can be interpreted as intensification of the cyclonic vorticity of the currents in the period of general water circulation activation in the eastern Black Sea.

In the occurred changes in the studied parameters both general trends and the specific to each type of halocline features are present.

Correlation evaluation of the relationship of average annual changes in the characteristics of $I$ and $H$, occurring in different types of halocline (Tab. 1), primarily points on the synchronicity of these changes (relations of II and $\mathrm{HH}$ ). Most significantly synchrony is peculiar to the characteristics of the north-eastern subarea halocline. Asynchrony of the relations $I$ and $H$ is less resistant; it may indicate the different nature of the factors governing long-term changes $I$ and $H$. In the southeastern subarea significant asynchronous communication $I H$ exists only in DAE areas.

Across the eastern region of the sea and the south-eastern subarea the changes in DAE halocline may be considered more indicative as their relationship to the changes in other areas are characterized by higher correlation coefficients. And in the case of increasing the size of the data subarea spatial averaging from the subarea to half of the sea, the correlation coefficients increased. The degree of correlation $\left(\left|k_{\text {med }}\right|\right)$ of the characteristics of the considered halocline types is shown in the following diagram:

Eastern part of
the sea
SAE 0.43 CE
$0.49 \quad 0.61$
DAE

North-eastern
subarea
SAE $0.44 \quad$ CE
$\begin{gathered}0.44 \quad 0.43 \\ \text { DAE }\end{gathered}$

DAE

\section{South-eastern subarea \\ SAE 0.23 CE \\ $0.44 \quad 0.30$}

DAE

Table 1. Correlation coefficients $k$ of the statistically proved relations of the changes of the average annual characteristics of the research constant halocline types in the eastern Black sea

\begin{tabular}{|c|c|c|c|c|c|c|c|c|c|c|c|c|c|c|c|c|c|c|c|}
\hline \multirow{3}{*}{ 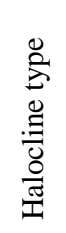 } & \multirow{3}{*}{ 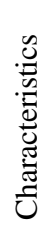 } & \multicolumn{6}{|c|}{$\begin{array}{l}\text { Eastern part of } \\
\text { the sea }\end{array}$} & \multicolumn{6}{|c|}{$\begin{array}{c}\text { North-eastern } \\
\text { subarea }\end{array}$} & \multicolumn{6}{|c|}{$\begin{array}{c}\text { South-eastern } \\
\text { subarea }\end{array}$} \\
\hline & & \multicolumn{2}{|c|}{ SAE } & \multicolumn{2}{|c|}{$\mathrm{CE}$} & \multicolumn{2}{|c|}{ DAE } & \multicolumn{2}{|c|}{ SAE } & \multicolumn{2}{|c|}{ CE } & \multicolumn{2}{|c|}{ DAE } & \multicolumn{2}{|c|}{ SAE } & \multicolumn{2}{|c|}{ CE } & \multicolumn{2}{|c|}{ DAE } \\
\hline & & $I$ & $H$ & $I$ & $H$ & $I$ & $H$ & $I$ & $H$ & $I$ & $H$ & $I$ & $H$ & $I$ & $H$ & $I$ & $H$ & $I$ & $H$ \\
\hline \multirow{2}{*}{ SAE } & $I$ & & -0.39 & \begin{tabular}{|l}
0.63 \\
\end{tabular} & -0.31 & \begin{tabular}{|l}
0.68 \\
\end{tabular} & -0.45 & & -0.4 & 0.60 & -0.46 & 0.60 & -0.51 & & - & \begin{tabular}{|l|}
0.51 \\
\end{tabular} & - & 0.61 & -0.31 \\
\hline & $H$ & & & -0.28 & \begin{tabular}{|l|l|}
0.50 \\
\end{tabular} & - & 0.84 & & & -0.28 & 0.40 & - & 0.64 & & & - & 0.41 & - & 0.82 \\
\hline \multirow{2}{*}{$\mathrm{CE}$} & $I$ & & & & -0.59 & 0.68 & -0.59 & & & & -0.66 & 0.56 & -0.51 & & & & - & 0,42 & -0.38 \\
\hline & $H$ & & & & & -0.44 & 0.73 & & & & & - & 0.66 & & & & & - & 0.40 \\
\hline \multirow{2}{*}{ DAE } & $I$ & & & & & & -0.54 & & & & & & -0.49 & & & & & & -0.50 \\
\hline & $H$ & & & & & & & & & & & & & & & & & & \\
\hline
\end{tabular}

$\mathrm{N}$ o t e. The implementation level of the possible relations is $78 \%$ (in 35 cases of 45 possible). The correlation coefficient values of the relations $I I$ and $H H$ are shown in bold type. 
In the interannual changes (after excluding linear trend) the implementation level of possible relations of the researched characteristics decreased from 78 to $53 \%$ at the expense of reduction of the asynchronic relations $I H$ for the whole eastern Black Sea. The correlation coefficients also reduced. Decreasing the data averaging scales up to level of the subareas, the marked relations generally remained. Synchronic relations II and $H H$ were more resistant. Along the whole eastern region of the sea and in the north-eastern subarea the halocline changes in $\mathrm{SAE}$ areas were found to be the most demonstrative. In the south-eastern subarea the key role of the halocline changes in DAE areas remained.

Researching the average annual values of the halocline characteristics the halocline upwelling compensation principle in $\mathrm{CE}$ areas by its downwelling in the anticyclonic eddy areas did not manifest. I. e. processes of the discussed spatiotemporal scales don't reflect the spatial changes of the halocline characteristics, caused by eddy structure of the Black Sea currents.

Relationship of the average seasonal changes of the characteristics $I$ and $H$ are shown on Tab. 2. Linear trend exception from the range of these values didn't actually influence their relationship degree. Averaging both the indices of the whole eastern region of the sea and the changes of the average annual values (Tab.1), all possible relations of $I I$ and $H H$ type are realized. The most demonstrative are the changes in SAE halocline.

The following diagram shows the degree of the relationship $\left(\left|k_{\text {med }}\right|\right)$ between the characteristics of the discussed halocline types.

\section{Before trend exclusion \\ SAE $0.28 \quad$ CE \\ $0.35 \quad 0.25$}

DAE
After trend exclusion

SAE $0.26 \quad$ CE

$0.47 \quad 0.17$

DAE

Table 2. Correlation coefficients $k$ of the statistically proved relations of the changes of the average annual characteristics of the research constant halocline types in the eastern Black sea (before and after linear trend exclusion)

\begin{tabular}{|c|c|c|c|c|c|c|c|c|c|c|c|c|c|}
\hline \multirow{3}{*}{$\begin{array}{l}\text { Halocline } \\
\text { type }\end{array}$} & \multirow{3}{*}{$\begin{array}{c}\text { Characteristi } \\
\text { cs }\end{array}$} & \multicolumn{6}{|c|}{ Before trend exclusion } & \multicolumn{6}{|c|}{ After trend exclusion } \\
\hline & & \multicolumn{2}{|c|}{ SAE } & \multicolumn{2}{|c|}{ CE } & \multicolumn{2}{|c|}{ DAE } & \multicolumn{2}{|c|}{ SAE } & \multicolumn{2}{|c|}{ CE } & \multicolumn{2}{|c|}{ DAE } \\
\hline & & $I$ & $H$ & $I$ & $H$ & I & $H$ & $I$ & $H$ & I & $H$ & $I$ & $H$ \\
\hline \multirow{2}{*}{ SAE } & $I$ & & -0.24 & 0.55 & -0.26 & 0.58 & - & & -0.26 & 0.51 & - & 0.53 & -0.28 \\
\hline & $H$ & & & - & 0.30 & - & 0.82 & & & -0.24 & 0.30 & -0.26 & \begin{tabular}{|l|l|}
0.81 \\
\end{tabular} \\
\hline \multirow{2}{*}{ CE } & $I$ & & & & -0.30 & \begin{tabular}{|l|l|}
0.30 \\
\end{tabular} & -0.27 & & & & -0.34 & - & -0.26 \\
\hline & $H$ & & & & & - & 0.42 & & & & & - & \begin{tabular}{|l|l|}
0.43 \\
\end{tabular} \\
\hline \multirow{2}{*}{ DAE } & $I$ & & & & & & - & & & & & & - \\
\hline & $H$ & & & & & & & & & & & & \\
\hline
\end{tabular}

$\mathrm{N}$ o t e. Before trend exclusion the implementation level of the possible relations is $67 \%$ (in 10 cases of 15 possible). After trend exclusion the implementation level of the possible relations is $73 \%$ (in 11 cases of 15 possible). The correlation coefficient values of the synchronic relations II and $\mathrm{HH}$ are shown in bold type. 
Reducing the spatial averaging of the seasonal halocline characteristics up to the subarea size, the less resistant relations in the long-term changes of II remained and the more resistant ones in the previous variants of the $\mathrm{HH}$ analysis - disappear.

Graphical representation of the halocline depth position seasonal changes in DAE and CE areas in two subareas (Fig. 3) shows periods of asynchronic compensation changes. In the north-eastern subarea this asynchrony is sufficiently stable in October - November and is stipulated to the same extent by intensification of the both cyclonic and anticyclonic vorticity of the currents. In the south-eastern subarea the compensation vertical halocline movements are observed in various seasons, but are accompanied by stable alternation of the activation seasons and vorticity weakening. In 1984, 1985 and 1987 the vorticity intensification occurred in January - March, in 1983, 1988 and 1989 - in July - September, in 1987 the vorticity of currents intensified also in October - December. In 1986 the halocline depth position in the water upwelling and downwelling areas changed synchronically, that could be evidence of prevailing of the more global factors than regional seasonal changes of the vorticity intensification of currents.
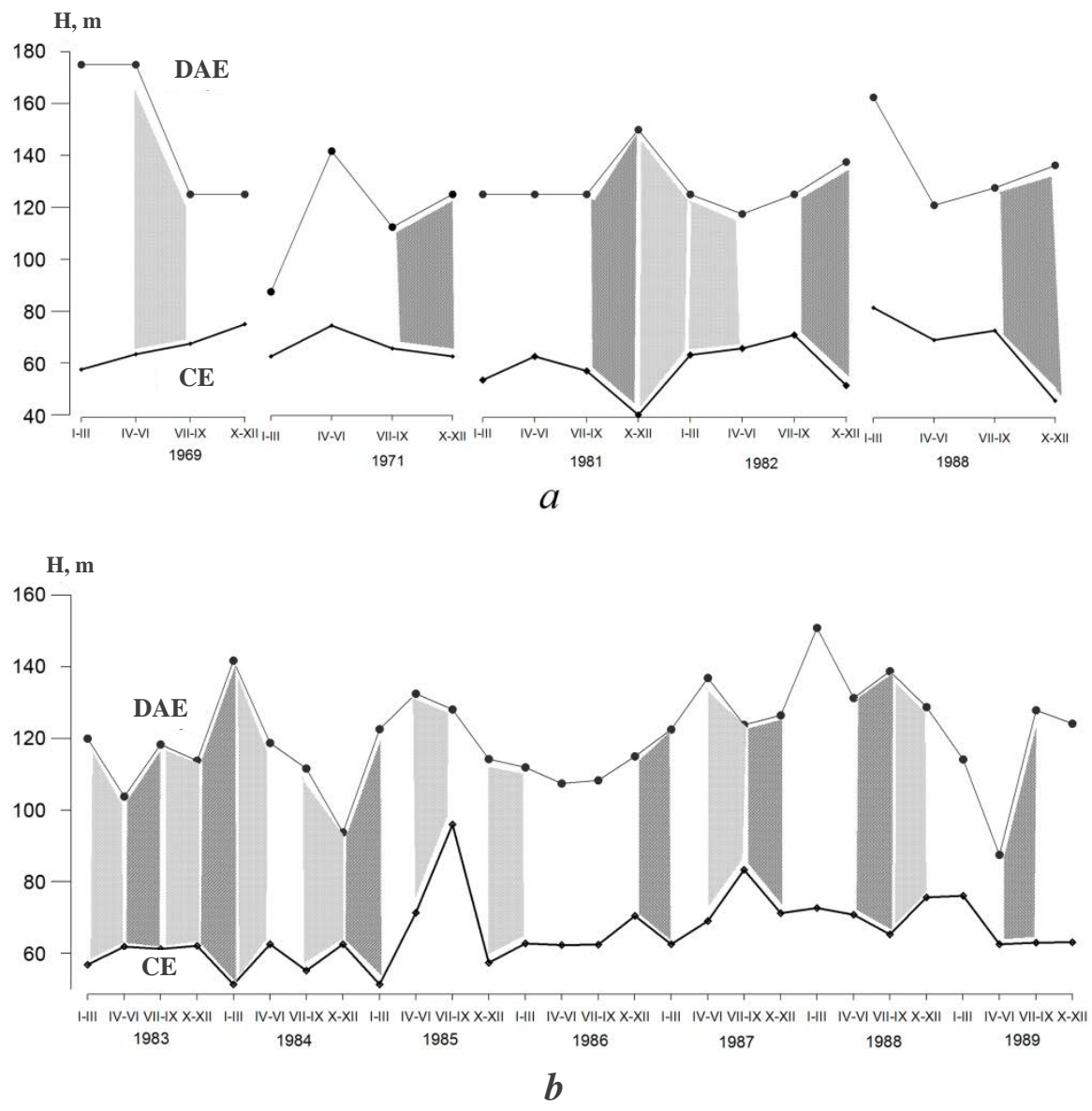

Fig. 3. Seasonal constant halocline depth position changes in CE and DAE areas in the eastern Black Sea: $a$ - north-eastern subarea, $b$ - south-eastern subarea $(\square$ - periods of the compensation halocline movements during vorticity intensification of currents; $\square$ - periods of the compensation halocline movements during vorticity weakening of currents) 
Consequently, the circulation nature of the differently directed vertical halocline movements can be manifested in reduction of the data time averaging to the seasonal values, and in the space - to the dimensions $2^{\circ}$ lat. $\times 4^{\circ}$ long.

Thus, intensification of currents in the halocline layer in the eastern Black Sea in the studied years mainly occurred in the autumn-winter period, however, in the south-eastern subarea the most intense circulation activity was observed in summer. The revealed seasonal peculiarities of the constant halocline vertical movements in the eastern Black Sea do not contradict to the contemporary conception about the seasonal changes of the water circulation in the layer $0-300 \mathrm{~m}[4,10]$.

Possible causes of the long-term changes of the indices researched and their role in transformations of the Black Sea ecosystem biotical characteristics were discussed in the article [13].

Conclusion. These peculiarities of spatial-temporal changes of maximum salinity gradient and depth of its position in the layer of the constant halocline in the eastern Black Sea in the areas of upwelling and downwelling of the cyclonic waters, deep and small anticyclonic eddies allow us to make a number of basic generalizations, conclusions and assumptions, as follows:

1. The main feature of the discussed processes was the predominance of synchronicity in the changes of salinity gradients and depth position of the halocline in various dynamic formations. Compensation asynchrony of the halocline vertical movements may show during the decrease in the data time averaging to seasonal values, and in the space - to the dimensions $2^{\circ}$ lat. $\times 4^{\circ}$ long. This results in increased attention to the research regionalization.

2. The use of the proposed indices allowed establishing in the long-term changes of the halocline characteristics the greater representation of the processes occurring in the deep anticyclonic eddies. For the interannual and seasonal changes more significant are the processes in the small anticyclonic eddies.

3. In the north-eastern subarea the vorticity intensification was observed quite stable in October - December and was due in equal measure to the strengthening of cyclonic and anticyclonic vorticity of currents. In the south-eastern subarea the vorticity intensification occurred in January - March (in 1984, 1985 and 1987) and in July - September (in 1983, 1988 and 1989). This time the anticyclonic vorticity intensification is more pronounced, which results in some years, non-traditional seasonal course of intensity of water circulation in this subarea.

4. The revealed seasonal peculiarities of the constant halocline vertical movements in the eastern Black Sea do not contradict to the contemporary conception about the seasonal changes of the water circulation in the layer $0-300 \mathrm{~m}$.

5. The results obtained indicate the possibility of using the proposed constant halocline indices in the research of peculiarities of water circulation and ecosystem functions of the Black Sea synoptic eddies; they may also be useful in the planning of model experiments.

\section{REFERENCES}

1. $\quad$ Eremeev, V.N., Ivanov, V.N. \& Tuzhilkin, V.S., 1991, “Klimaticheskie cherty vnutrigodovoy izmen-chivosti gidrofizicheskikh poley shel'fovoy zony Chernogo morya [Climatic features of the within-year variability of the Black Sea shelf hydrophysical areas]”, Sevastopol, 53 p. (in Russian). 
2. $\quad$ Blatov, A.S., Ivanov, V.A., 1979, “O vikhreobrazovanii v Chernom more [On eddy formation in the Black Sea]”, Kompleksnye issledovaniya Chernogo morya, pp. 43-51 (in Russian).

3. Golubev, Yu.N., Tuzhilkin, V.S., 1990, "Nekotorye aspekty sinopticheskoy izmenchivosti gidrofizicheskikh poley Chernogo morya [Some aspects of the synoptic variability of the Black Sea hydrophysical fields]”, 73 p. (in Russian).

4. Knysh, V.V., Kubryakov, A.I., Inyushina, N.V. \& Korotaev, G.K., 2008, "Vosstanovlenie klimaticheskoy sezonnoy tsirkulyatsii Chernogo morya na osnove modeli $v \sigma$-koordinatakh $s$ ispol'zovaniem assimilyatsii dannykh o temperature i solenosti [Renewal of the Black Sea climatic seasonal circulation on the basis of model in sigma-coordinates with the use of temperature and salinity data assimilation]", Ekologicheskaya bezopasnost' pribrezhnoy $i$ shel'fovoy zon i kompleksnoe ispol'zovanie resursov shel'fa, vol. 16, pp. 243-265 (in Russian).

5. Efimov, V.V., 2005, "Izmenenie klimata Chernomorskogo regiona [The Black Sea region climate changes]”, Ekologicheskaya bezopasnost' pribrezhnoy i shel'fovoy zon i kompleksnoe ispol'zovanie resursov shel'fa, vol. 13, pp. 322-334 (in Russian).

6. Belokopytov, V.N., Shokurova, I.G., 2005, “Otsenki mezhdesyatiletney izmenchivosti temperatury i solenosti $v$ Chernom more $v$ period 1951-1995 gg. [Estimates of Temperature and Salinity Interdecadal Variability in the Black Sea in 1951-1995]”, Ekologicheskaya bezopasnost' pribrezhnoy i shel'fovoy zon i kompleksnoe ispol'zovanie resursov shel'fa, vol. 12, pp. 12-21 (in Russian).

7. Knysh, V.V., Kubryakov, A.I. \& Moiseenko,V.A. [et al.], 2008, “Tendentsii v izmenchivosti termokhalinnykh i dinamicheskikh kharakteristik Chernogo morya, vydelennye po rezul'tatam reanaliza za period 1985-1994 gg. [Variability trends of thermohaline and dynamic characteristics of the Black Sea, selected according to the re-analysis results for the period of 1985 - 1994], Ekologicheskaya bezopasnost' pribrezhnoy i shel'fovoy zon i kompleksnoe ispol'zovanie resursov shel'fa, vol. 16, pp. 279-290 (in Russian).

8. Shokurova, I.G., 2007, “Analiz mezhdekadnoy izmenchivosti geostroficheskoy tsirkulyatsii vod Chernogo morya $v$ zimniy period [Interdecade variability of the geostrophic Black Sea water circulation in winter period], Sistemy kontrolya okruzhayushchey sredy, pp. 276-279 (in Russian).

9. Belokopytov, V.N., Shokurova, I.G. \& Polonskii, A.B., 2011, “O desyatiletney izmenchivosti temperatury i solenosti $v$ sloe postoyannogo piknoklina $v$ Chernom more [On the decade temperature and salinity variability in the Black Sea constant halocline layer]", Ekologicheskaya bezopasnost' pribrezhnoy i shel'fovoy zon i kompleksnoe ispol'zovanie resursov shel'fa, vol. 15, pp. 223-225 (in Russian).

10. Shokurova, I.G., 2008, “Sezonnaya i mezhdekadnaya izmenchivost' geostroficheskoy tsirkulyatsii vod Chernogo morya [Seasonal and inter-decade variability of the geostrophic Black Sea water circulation]", Sistemy kontrolya okruzhayushchey sredy: Mezhdunar. nauch.-tekhn. seminar, 15-19 sentyabrya 2008 g., pp. 329-332 (in Russian).

11. Panov, B.N., 2008, "Svyazi okeanograficheskikh kharakteristik vod yugo-vostochnoy chasti Chernogo morya [Oceanographic feature relations of the south-eastern Black Sea waters]", Sistemy kontrolya okruzhayushchey sredy: Mezhdunar. nauch.-tekhn. seminar, 15 - 19 sentyabrya 2008 g., pp. 282-286 (in Russian).

12. Panov, B.N., 2010, “Vozmozhnosti ispol'zovaniya kharakteristik osnovnogo chernomorskogo galoklina $v$ issledovaniyakh dinamiki sostoyaniya chernomorskoy ekosistemy [Possibilities of applying the main Black Sea halocline characteristics in the research of the Black Sea ecosystem dynamics]", Ekologicheskaya bezopasnost' pribrezhnoy i shel'fovoy zon $i$ kompleksnoe ispol'zovanie resursov shel'fa, vol. 22, pp. 83-96 (in Russian).

13. Panov, B.N., Spiridonova, E.O., 2011, "Mnogoletnie izmeneniya i ekosistemnye svyazi kharakteristik osnovnogo chernomorskogo galoklina, predstavlennykh $v$ kachestve pokazateley tsirkulyatsii vod [Long-term changes and ecosystem relations of the main Black Sea halocline, presented as the water circulation indicators]”, Uch. zap. Tavricheskogo nats. u-ta im. V.I. Vernadskogo, vol. 24 (63), no. 3, pp.78-90 (in Russian). 